\title{
Effect of post-grazing residual leaf blade-length on the regrowth vigor of Piatã grass grazed under intermittent stocking
}

\section{Efeito do comprimento residual de lâmina foliar pós-pastejo no vigor de rebrotação de capim Piatã pastejado sob lotação intermitente}

\author{
Wagner Soares da Costa Junior ${ }^{1 *}$; Emerson Alexandrino ${ }^{2}$; \\ Joaquim José de Paula Neto ${ }^{3}$; José Messias de Rezende ${ }^{4}$
}

\begin{abstract}
The objective of this study was to evaluate the effect of post-grazing residual leaf blades (RLB) of different lengths on the morphogenic and structural characteristics of Urochloa brizantha 'Piatã' grazed upon by beef cattle. A completely randomized design was used, with three RLB lengths (2, 4, and $6 \mathrm{~cm}$ ) and two paddocks as replicates over two grazing seasons (wet and wet-dry transition). To monitor the weekly forage growth, two representative clumps and 48 tillers per treatment were marked after grazing. The procedure continued until the plants reached the target pre-grazing height of 35-40 $\mathrm{cm}$. Morphogenic characteristics were not affected by the treatments or seasons, with minor changes observed in mean sheath length (MSL) within season and tiller population density (TPD). The MSL reached its peak value of $210.37 \mathrm{~mm}$ during the wet season relative to $175.89 \mathrm{~mm}$ during the wetdry transition. The TPD reached its lowest value $\left(680\right.$ tillers $\left.\mathrm{m}^{-2}\right)$ at the highest defoliation intensity $(2 \mathrm{~cm})$ relative to that at the lowest defoliation intensity $\left(720\right.$ tillers $\left.\mathrm{m}^{-2}\right)$. The different RLB lengths modified canopy height variably; canopy height was the highest with the $6 \mathrm{~cm}$ leaves $(24.31 \mathrm{~cm})$, but did not vary between the $2 \mathrm{~cm}$ and $4 \mathrm{~cm}$ leaves. The post-grazing leaf area index and interception of photosynthetically active radiation were modified by season. The highest defoliation intensity $(2 \mathrm{~cm})$ increased the rest period by seven days when compared with the lowest defoliation intensity $(6 \mathrm{~cm})$. Key words: Canopy height. Grazing management. Morphogenesis. Defoliation.
\end{abstract}

\section{Resumo}

Objetivou-se avaliar o efeito de diferentes comprimentos de lâmina foliar residual (RLF) pós-pastejo sobre as respostas morfogênicas e estruturais do capim Urochloa brizantha cv. Piatã pastejado por bovinos de corte. $\mathrm{O}$ delineamento experimental utilizado foi o inteiramente casualizado, com três RLF $(2,4$ e $6 \mathrm{~cm})$ e duas repetições de piquetes, ao longo de duas estações (águas e transição águas-seca). Após o pastejo dos bovinos eram marcadas duas touceiras representativas, e 48 perfilhos por tratamento, para o acompanhamento semanal do crescimento forrageiro, durante o período necessário para as plantas atingirem as metas de alturas pré-pastejo determinada entre 35 e $40 \mathrm{~cm}$. As características morfogênicas não diferenciaram entre os tratamentos e estações, que promoveu pouca alteração nas características estruturais, apenas comprimento médio de bainha (CMB) na estação e densidade populacional de perfilhos (DPP). O maior valor encontrado para CMB, foi na estação das águas $210,37 \mathrm{~mm}$ versus

\footnotetext{
${ }^{1}$ Dr. em Ciência Animal Tropical, Universidade Federal do Tocantins, UFT, Araguaína, TO, Brasil. E-mail: wjr_zootecnia@ hotmail.com

2 Prof. Dr., Colegiado de Zootecnia, UFT, Araguaína, TO, Brasil. E-mail: e_alexandrino@yahoo.com.br

3 Dr. em Ciência Animal Tropical, UFT, Araguaína, TO, Brasil. E-mail: jneto@zootecnista.com.br

4 Discente, Curso de Doutorado, Programa de Pós-Graduação em Ciência Animal Tropical, UFT, Araguaína, TO, Brasil. E-mail: messyas10@hotmail.com
}

* Author for correspondence 
$175,89 \mathrm{~mm}$ para a transição. A DPP apresentou o menor valor (680 perfilhos $\left.\mathrm{m}^{-2}\right)$ com a maior remoção $(2 \mathrm{~cm})$ em relação ao de menor remoção $\left(720\right.$ perfilhos $\left.\mathrm{m}^{-2}\right)$. As diferentes remoções de lâmina foliar proporcionou alteração na altura de saída, em que o tratamento $6 \mathrm{~cm}$ apresentou a maior altura $(24,31$ $\mathrm{cm}$ ), não diferenciando os demais tratamentos. O índice de área foliar (IAF) e interceptação da radiação fotossinteticamente ativa (IRFA) foram modificados no pós pastejo. A maior remoção de lâmina foliar $(2 \mathrm{~cm})$ teve o seu período de descanso (PD) aumentado em 7 dias, em relação a menor remoção $(6 \mathrm{~cm})$.

Palavras-chave: Altura de dossel. Manejo do pastejo. Morfogênese. Remoção foliar.

\section{Introduction}

Grazing management aims to maximize leaf production at the cost of stems, thus positively affecting forage prehension and digestion. Therefore, it is necessary to identify the physiological and morphological adaptations of forage plants to grazing (DIFANTE et al., 2011; SANTOS et al., 2011a). The challenge is to optimize the efficiency of forage harvest without compromising the perenniality of the forage canopy (ALEXANDRINO et al., 2008).

Knowledge of the forage accumulation process together with grazing response helps understand the adaptation of grasses to the imposed management system. The appearance of leaves, elongation of leaves and stems, and leaf lifespan are the morphogenic characteristics that determine forage accumulation rates. These traits form the basis of the canopy structure, which determine the leaf area index (LAI). Therefore, the quantity and quality of radiation intercepted by the plant are interrelated with the leaf to stem ratio, which defines the ease of forage prehension (DIFANTE et al., 2008; LARA; PEDREIRA, 2011).

Forage plants submitted to different grazing intensities can undergo alteration in the proportion of their morphological and structural components, which determine forage yield and animal performance. Therefore, adequate grazing management is critical to the production system (AGUINAGA et al., 2008; SANTOS et al., 2011b).

Under intermittent grazing, the postgrazing residual leaf blade (RLB) length can be used as a guideline for grazing management because defoliation intensity can alter the morphophysiological and structural characteristics of the plant, directly affecting animal performance (CÂNDIDO et al., 2005b; GALZERANO et al., 2013; MARCELINO et al., 2006).

Variations in the post-grazing RLB length can modify the entire production system, and induce changes from fluctuations in the rest period, which might require a higher number of paddocks under intermittent grazing, to changes in animal weight gain due to altered feeding behavior. Furthermore, the perenniality of the system can be modified depending on regrowth vigor.

The objective of the present study was to evaluate the effect of post-grazing RLB lengths on the regrowth vigor of Urochloa brizantha 'Piatã' grass managed under intermittent grazing, with the pre-grazing canopy height of 35 to $40 \mathrm{~cm}$, and under different tropical conditions.

\section{Material and Methods}

The experiment was conducted at the Federal University of Tocantins, Campus Araguaína-TO, from November 7, 2014 to May 20, 2015, using Urochloa brizantha 'Piatã' pasture established in 2009/2010 by NEPRAL (Study Group of Ruminant Production in Legal Amazon), located at 0 $7^{\circ} 12^{\prime} 28^{\prime \prime}$ $\mathrm{S}$ latitude and $48^{\circ} 12^{\prime} 26^{\prime \prime} \mathrm{W}$ longitude, and altitude of $236 \mathrm{~m}$.

Based on the Köppen classification (1948), the climate is considered as Aw, tropical wet-dry climate, with a rainy season in summer, and, typically, a pronounced dry season. The maximum and minimum temperatures reach $40^{\circ} \mathrm{C}$ and $18^{\circ} \mathrm{C}$, respectively, and annual average relative humidity is $76 \%$, with average precipitation of $1937 \mathrm{~mm}$ recorded over the 
last three years. During the experimental period, the Campus Araguaína-TO, $800 \mathrm{~m}$ away from the precipitation and temperature data were collected experimental area (Figure 1).

at the INMET agrometeorological station located at

Figure 1. Precipitation during the experimental period (November 2014 to May 2015) measured at the INMET agrometeorological station in Araguaína-TO.

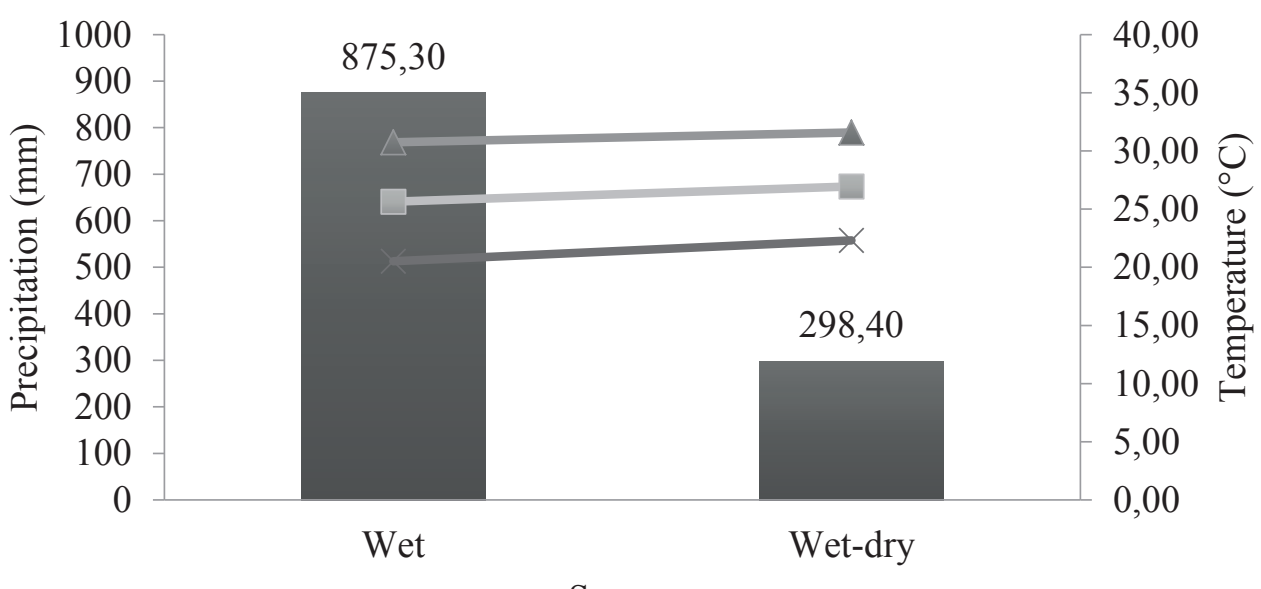

Season

Precipitation $(\mathrm{mm})-\operatorname{Mean} \mathrm{T}\left({ }^{\circ} \mathrm{C}\right) \multimap \operatorname{Max} . \mathrm{T}\left({ }^{\circ} \mathrm{C}\right) \multimap \operatorname{Min} . \mathrm{T}\left({ }^{\circ} \mathrm{C}\right)$

Source: INMET (National Institute of Meteorology).

The soil of the experimental area was classified 2013), which is one of the main soil classes in the as typical orthic Quartzarenic Neosol (EMBRAPA, State of Tocantins. Soil analyses are shown in Table 1.

Table 1. Chemical analysis of the soil from the experimental area at different depths in Piatã grass pastures.

\begin{tabular}{lccc}
\hline \multirow{2}{*}{ Chemical characteristics } & \multicolumn{3}{c}{ Depth $(\mathrm{cm})$} \\
\cline { 2 - 4 } & $0-5$ & $5-10$ & $10-20$ \\
\hline $\mathrm{pH}(\mathrm{CaCl})$ & 4.7 & 4.6 & 4.5 \\
$\mathrm{OM}\left(\mathrm{g} / \mathrm{dm}^{3}\right)$ & 15 & 14 & 12 \\
$\mathrm{P}\left(\mathrm{mg} / \mathrm{dm}^{3}\right)$ & 18 & 12 & 8 \\
$\mathrm{~K}^{+}\left(\mathrm{mg} / \mathrm{dm}^{3}\right)$ & 1.5 & 0.9 & 0.7 \\
$\mathrm{~S}\left(\mathrm{mg} / \mathrm{dm}^{3}\right)$ & 11 & 11 & 7 \\
$\mathrm{Ca}^{2+}\left(\mathrm{mmolc}^{3} \mathrm{dm}^{3}\right)$ & 9 & 6 & 5 \\
$\mathrm{Mg}^{2+}\left(\mathrm{mmolc} / \mathrm{dm}^{3}\right)$ & 7 & 3 & 3 \\
$\mathrm{H}+\mathrm{Al}\left(\mathrm{mmolc} / \mathrm{dm}^{3}\right)$ & 18 & 22 & 18 \\
$\mathrm{Base} \mathrm{saturation}(\%)$ & 47.12 & 29.08 & 30.82 \\
$\mathrm{Sum}$ of bases $\left(\mathrm{mmolc}^{3} / \mathrm{dm}^{3}\right)$ & 16.04 & 9.02 & 8.02 \\
$\mathrm{CEC}\left(\mathrm{mmolc} / \mathrm{dm}^{3}\right)$ & 34.04 & 31.02 & 26.02 \\
\hline
\end{tabular}

$\mathrm{OM}=$ Organic matter $\mathrm{P}=$ phosphorus $; \mathrm{K}=$ potassium $; \mathrm{S}=$ sulfur $; \mathrm{Ca}=$ calcium; $\mathrm{Mg}=$ magnesium $; \mathrm{H}+\mathrm{Al}=$ hydrogen + aluminum; $\mathrm{CEC}=$ cation exchange capacity. 
During the Piatã grass growing season, three post-grazing RLB lengths were determined based on different lengths of the upper canopy leaves, which consisted of the emerging leaf and the fully-expanded leaves that emerged during the last regrowth period. The RLB length was used as a guideline for grazing management to the detriment of canopy height, being a fine-adjustment strategy for the manipulation of the vertical (pre-grazing condition) versus horizontal (post-grazing) structure of the canopy during the grazing period.

Phosphate fertilizer (50 $\left.\mathrm{kg} \quad \mathrm{P}_{2} \mathrm{O}_{5} \mathrm{ha}^{-1}\right)$ was applied to the soil surface, in a single maintenance application, on October 2, 2014. Nitrogen (N) and potassium $\left(\mathrm{K}_{2} \mathrm{O}\right)$ fertilization were applied at $40 \mathrm{~kg}$ $\mathrm{ha}^{-1}$ during the first grazing cycle using the NPK 200-20 formulation. Fertilization application during the second grazing cycle onwards was performed as a function of the period required by the plants to reach the target canopy height $(35$ to $40 \mathrm{~cm})$. This resulted in an annual $\mathrm{N}$ fertilization of $200 \mathrm{~kg} \mathrm{ha}^{-1}$ during 175 days of the wet season, that is, $1.14 \mathrm{~kg}$ $\mathrm{ha}^{-1}$ of $\mathrm{N}$ per day of regrowth. Such fertilization management ensured similar total $\mathrm{N}$ and $\mathrm{K}_{2} \mathrm{O}$ application between treatments but at different rates per grazing cycle.

The experimental area consisted of 4.8 ha of Piatã grass, divided into six modules with four paddocks of 0.2 ha each, totaling two modules per treatment and a 2-ha escape area used to accommodate the non-tester animals. An intermittent grazing system was used, with adjustment of the stocking rate and establishment of start and end dates for grazing based on the forage canopy structure. Grazing began when the canopy height reached $35-40 \mathrm{~cm}$, which is considered the ideal range for the control of stems (MELO, 2014). During the period of occupation of approximately 12 days, the canopy was lowered based on each treatment. Canopy height was measured with a graduated ruler, represented by the average of 50 random points per paddock. The evaluated RLB lengths were 2, 4, and $6 \mathrm{~cm}$. Fifteen representative tillers per paddock were chosen to evaluate the emerging leaves and the two newly expanded leaves.

Because the grazing management was based on plant structure, the rest period had only a small variation. This resulted in different grazing cycles (48.7, 45.5, and 42.8 days) for the RLB treatments of 2,4 , and $6 \mathrm{~cm}$, respectively; the mean rest period and occupation period were 36.7 and 12, 34.5 and 11, and 30.8 and 12 days, respectively, fluctuating as a function of regrowth vigor. For data analysis, the four grazing cycles were distributed into two growing seasons (wet and wet-dry transition), with two cycles per season (Figure 1). For monitoring the morphogenic characteristics, 48 tillers per treatment were marked (DAVIES, 1993) 3 days after the grazing end date, in two paddocks, to evaluate the growth and senescence of leaf blades and stems. Two representative clumps were selected once a week for marking the tillers based on the mean canopy height of each paddock.

Field data was used to calculate the following parameters: leaf appearance rate (leaves tiller $^{-1}$ day $\left.^{-1}\right)$, leaf elongation rate $\left(\mathrm{mm}\right.$ tiller $^{-1}$ day $\left.^{-1}\right)$, stem elongation rate $\left(\mathrm{mm}\right.$ tiller ${ }^{-1}$ day $\left.^{-1}\right)$, leaf senescence rate $\left(\mathrm{mm}\right.$ tiller ${ }^{-1}$ day $\left.^{-1}\right)$, number of live leaves per tiller (leaves tiller-1), leaf lifespan (days), mean leaf length $\left(\mathrm{mm} \mathrm{leaf}^{-1}\right)$, mean sheath length $(\mathrm{mm}$ sheath $^{-1}$ ), and phyllochron (leaf ${ }^{-1}$ days).

Tiller population density was obtained by counting the tillers. Tillers were counted (in $\mathrm{m}^{-2}$ ) after each grazing cycle (post-grazing condition) by placing a quadrat of $1.0 \times 0.25 \mathrm{~m}\left(0.25 \mathrm{~m}^{-2}\right)$ at two different points per paddock based on the mean canopy height.

Pre- and post-grazing canopy light interception were measured with a canopy analyzer (SunScan Delta-T Device) between 10 a.m. and 2 p.m. at 20 random points along the paddock at the soil surface level. Then, the interception of photosynthetically active radiation (PAR) and LAI $\left(\mathrm{m}^{-2}\right.$ of leaves per $\mathrm{m}^{-2}$ of soil) were obtained. 
All evaluations were performed following the same sampling pattern. Overall, eight paddocks were distributed for each treatment, four of which were managed under intermittent grazing and, in half of them, two paddocks per module were evaluated. However, except for canopy height and light interception measurements that were randomly performed in the evaluated paddocks, all other evaluations were carried out at two points per paddock, representing the mean canopy height.

The treatments were distributed in a completely randomized design, with six treatments combining three RLB lengths and two growing seasons, with four replications (two paddocks $\times$ two points). The variables studied were subjected to a normality test (Shapiro-Wilk) and homoscedasticity (Levene's test) of variances, being grouped by season (wet: from December 20, 2014 to March 10, 2015 and wet-dry transition: from March 11, 2015 to May 20, 2015). The model evaluating morphogenetic and structural characteristics of the canopy included treatments (post-grazing leaf blade length), season, and leaf blade length vs. season interaction as fixed effects.
Analyses were performed using the PROC MIXED (mixed models) of the Statistical Analysis System (SAS, 1996) and the means were calculated using LSMEANS. Means were compared by Tukey's test at $5 \%$ probability. The covariance matrix was chosen by the Akaike information criterion (AIC and BIC) (WOLFINGER, 1993).

\section{Results and Discussion}

The obtained RLB values of $2.3,4.19$, and $6.29 \mathrm{~cm}$ were similar to those intended for the experimental treatments, i.e., 2, 4, and $6 \mathrm{~cm}$, respectively. During the experimental period, the pre-grazing height did not differ between the tested treatments and seasons (Figure 2) because of the grazing management imposed. An interaction between treatments and season on post-grazing height was observed, with higher values at $6 \mathrm{~cm}$ RLB regardless of the season. In contrast, the 2 and $4 \mathrm{~cm}$ RLBs were similar for this trait.

Figure 2. Pre-and post-grazing height of Piatã grass managed under different residual leaf blade (RLB) lengths.

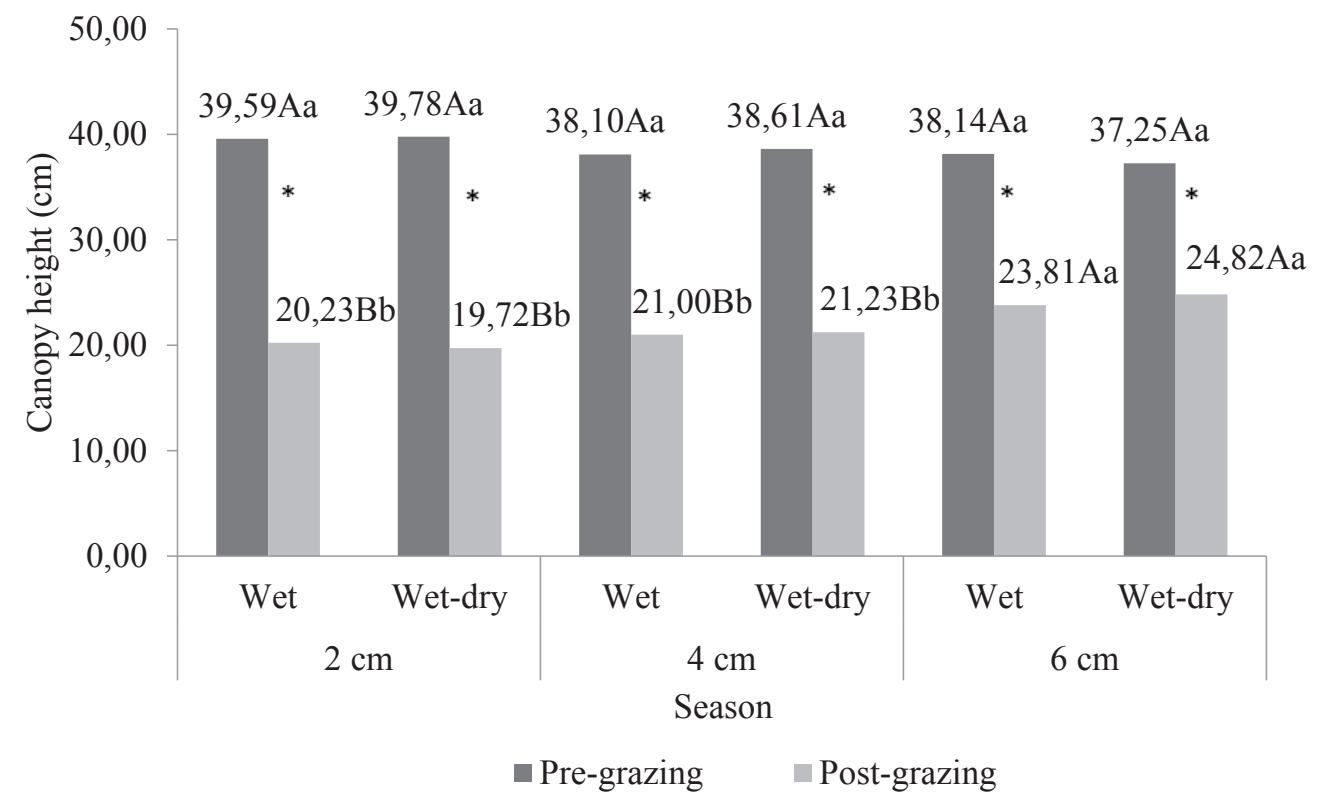

* = significant effect on pre- and post-grazing.

Lowercase letters compare post-grazing RLB lengths and uppercase letters compare seasons. Means followed by the same letter do not differ statistically by the Tukey's test at $5 \%$ probability. 
The lower post-grazing heights for the 2 and 4 $\mathrm{cm}$ RLBs can be explained by the greater need of searching for leaves in the canopy during grazing, which decreased post-grazing leaf dry matter, with values of $828.64,717.57$, and $542.59 \mathrm{~kg}$ ha at 6,4 , and $2 \mathrm{~cm}$ RLB, respectively. A similar effect was observed by Nantes et al. (2013) in Piatã grass, in which reduction in available forage was associated with reduced canopy height. Although the pattern of forage searching was not evaluated in the present study, it was modified by the reduction in RLB length. We hypothesized that the small difference in canopy height between treatments was the result of higher searching effort by cattle. Under this circumstance, the stem proportion begins to predominate as the leaf component decreases, which impairs the reduction in canopy height.

The morphogenetic characteristics, i.e., leaf appearance rate (LAR), phyllochron (PHYLLO), leaf elongation rate (LER), stem elongation rate, (SER) and leaf senescence rate (LSR) were not altered by the grazing management and season during the growing period (Table 2). This demonstrates that the forage plant adapted to the given conditions, evidencing the phenotypic plasticity of this cultivar, which is similar to that shown for Marandu grass (SBRISSIA; SILVA, 2008). A similar leaf appearance rate response was observed by Marcelino et al. (2006) in Marandu grass managed under two grazing intensities (10 and $20 \mathrm{~cm}$ obtained 0.079 and $0.076 \mathrm{~mm}$ leaf tiller $^{-1}$ day $^{-1}$, respectively). Casagrande et al. (2010) studied Marandu grass and did not observe any differences in the PHYLLO for different forage availabilities, with an average of 11.2 days. The rest period was inversely proportional to RLB length, being 36.7, 34.5, and 30.8 days for 2, 4, and $6 \mathrm{~cm}$ RLB, respectively. This small variation ensured full recovery of the current tillers without any change in their individual growth; however, there might have been some influence on the production of new tillers.

Table 2. Leaf appearance rate, phyllochron, leaf elongation rate, stem elongation rate, and leaf senescence rate of Piatã grass managed under intermittent grazing.

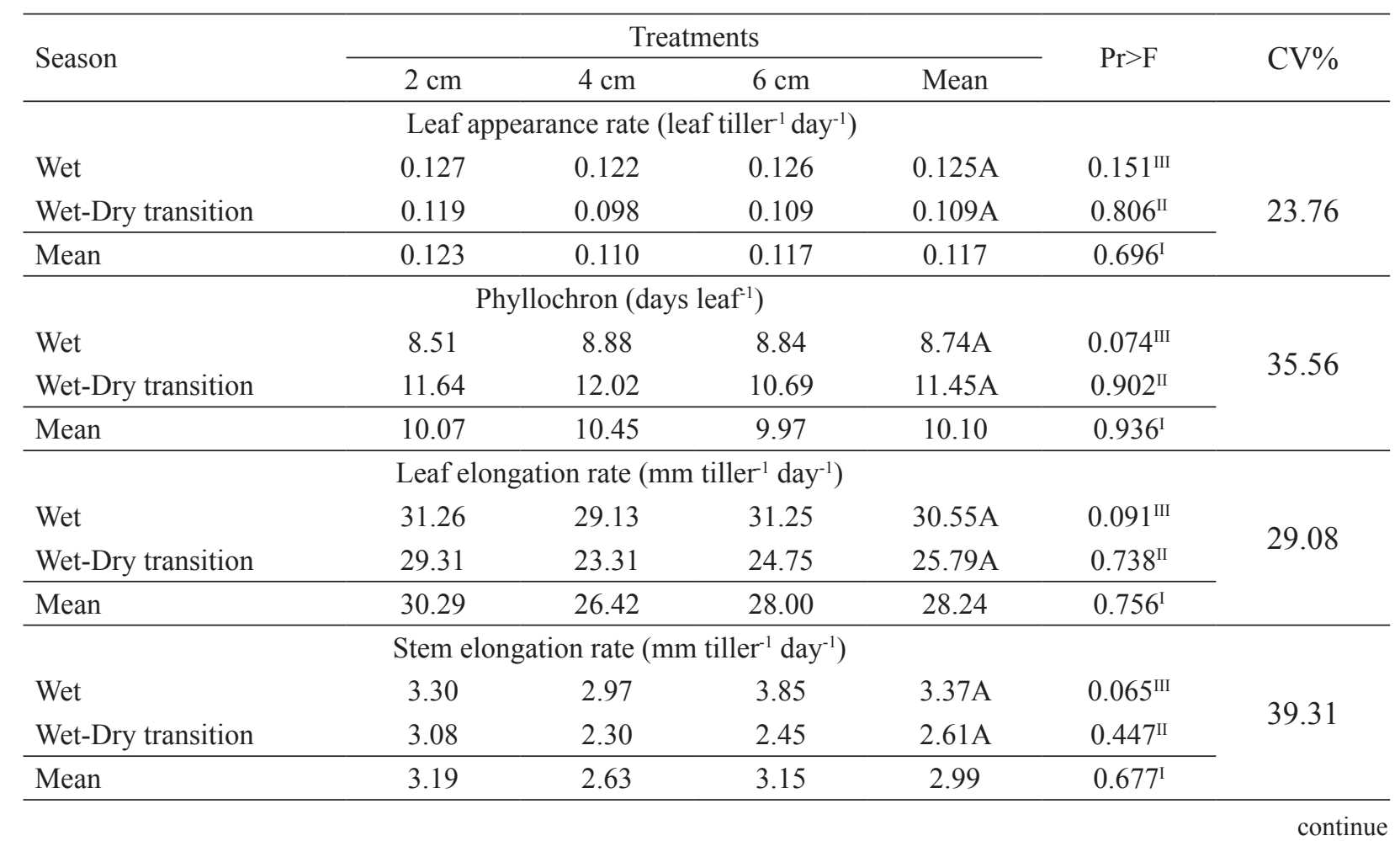


continuation

\begin{tabular}{lcccccc}
\hline & \multicolumn{6}{c}{ Leaf senescence rate $\left(\mathrm{mm} \mathrm{tiller}^{-1}\right.$ day $\left.^{-1}\right)$} \\
Wet & 7.13 & 5.65 & 6.62 & $6.47 \mathrm{~A}$ & $0.154^{\mathrm{III}}$ & \multirow{2}{*}{21.02} \\
Wet-Dry transition & 5.41 & 5.81 & 5.61 & $5.61 \mathrm{~A}$ & $0.410^{\mathrm{II}}$ & \\
\cline { 1 - 6 } Mean & 6.27 & 5.73 & 6.11 & 6.04 & $0.579^{\mathrm{I}}$ & \\
\hline
\end{tabular}

Means followed by similar lowercase letters within rows and uppercase letter within columns are not significantly different at $\mathrm{P}<$ 0.05 (Tukey's test). P value: I - treatment; II - interaction; III - season. CV\% = coefficient of variation.

The treatments tested were effective at controlling stem elongation, which is one of the main aims of grazing management in tropical grasses. The mean value found was $2.99 \mathrm{~mm}_{\text {tiller }}{ }^{-1}$ day $^{-1}$. Stem elongation interferes directly with grazing efficiency due to the narrowing of the leaf to stem ratio, which is not desirable when aiming for a high-quality forage (CUTRIM JÚNIOR et al., 2010; RODRIGUES et al., 2014).

The leaf senescence rate averaged $6.04 \mathrm{~mm}_{\text {tiller }}{ }^{-1}$ day $^{-1}$, with no difference between treatments and seasons. A similar result was found by Melo (2014) for Piatã grass at $6.27 \mathrm{~mm}_{\text {tiller }}{ }^{-1}$ day $^{-1}$. Generally, this characteristic is altered when using different pre-grazing heights owing to competition for light (CASAGRANDE et al., 2010). The lifespan of leaves is determined genetically; however, it is also affected by the environment, with the similarity in RLB length derived from at least two factors. First, the most extended rest period of approximately 37 days at the lowest RLB length was compatible with the leaf lifespan, which should reach 40 days (four live leaves tiller ${ }^{-1} \times$ ten days leaf ${ }^{-1}-$ phyllochron). Then, the leaves were grazed before senescence. Second, the remaining leaf tissue was relatively decreased after harvesting.

The recovery of the forage canopy after harvesting or grazing occurs due to the processes of elongation and senescence of leaves and tillers. During the recovery period, growth may change based on the availability of resources such as water, light, nitrogen, and temperature (CÂNDIDO et al., 2005a, b; DIFANTE et al., 2008). Considering that the study was conducted under the same environmental and fertilization conditions, the morphogenic variables did not change.

Structural variables are affected by changes in morphogenic responses and by the frequency and intensity of cutting or grazing (DIFANTE et al., 2008). Because the morphogenic characteristics were not responsive to the RLB lengths, the structural characteristics such as the number of live leaves per tiller-1 (NLL), leaf lifespan (LLS), mean leaf length, (MLL) and mean sheath length (MSL) were also unaffected by the RLB lengths (Table 3). Generally, lower managed canopies have altered structural characteristics (LARA; PEDREIRA, 2011). However, the pre-grazing height of 35 to 40 $\mathrm{cm}$ contributed to the similarity between variables under different RLB lengths, allowing for proper plant recovery. This emphasizes the importance of frequency and grazing intensity in management recommendations. Furthermore, the post-grazing residual heights of 19.97, 21.11, and $24.31 \mathrm{~cm}$ for 2 , 4, and $6 \mathrm{~cm}$ RLBs, respectively, were similar.

Differences were found in MSL within seasons and tiller population density (TDP) at different RLB lengths. The increased MSL to $34.48 \mathrm{~mm}$ during the wet season was associated with favorable environmental conditions for growing (LARA; PEDREIRA, 2011). The precipitation during the wet season reached $875.3 \mathrm{~mm}$, whereas in the wetdry transition it reached $298.4 \mathrm{~mm}$, or $34.09 \%$ of the total. Forage plants have priorities in tissue deposition, with the leaf component having the highest priority. Under water-restriction conditions, the lowest priority component is penalized. Similarly, Galzerano et al. (2013) observed the influence of 
greater precipitation on final stem length (12.70 to $19.95 \mathrm{~cm}$ ) in Xaraés grass. Greater stem elongation under high precipitation conditions might be related to low insolation, which is a strategy of the plant to elongate the stem and expose young and more photosynthetically active leaves to higher amounts of light (GALZERANO et al., 2013; SANTOS et al., 2011a).

Table 3. Number of live leaves per tiller ${ }^{-1}$, leaf lifespan, mean leaf length, mean sheath length (MSL), and tiller population density (TPD) of Piatã grass managed under intermittent grazing.

\begin{tabular}{|c|c|c|c|c|c|c|}
\hline \multirow{2}{*}{ Season } & \multicolumn{4}{|c|}{ Treatments } & \multirow{2}{*}{$\operatorname{Pr}>\mathrm{F}$} & \multirow{2}{*}{$\mathrm{CV} \%$} \\
\hline & $2 \mathrm{~cm}$ & $4 \mathrm{~cm}$ & $6 \mathrm{~cm}$ & Mean & & \\
\hline \multicolumn{7}{|c|}{ Number of live leaves (tiller-1) } \\
\hline Wet & 4.56 & 4.73 & 4.54 & $4.61 \mathrm{~A}$ & $0.131^{\mathrm{III}}$ & \multirow{3}{*}{7.23} \\
\hline Wet-Dry transition & 4.60 & 4.26 & 4.35 & $4.40 \mathrm{~A}$ & $0.302^{\mathrm{II}}$ & \\
\hline Mean & $4.58 \mathrm{a}$ & $4.50 \mathrm{a}$ & $4.45 \mathrm{a}$ & 4.51 & $0.692^{\mathrm{I}}$ & \\
\hline \multicolumn{7}{|c|}{ Leaf lifespan (days) } \\
\hline Wet & 37.56 & 40.44 & 38.65 & $38.88 \mathrm{~A}$ & $0.119^{\mathrm{III}}$ & \multirow{3}{*}{29.13} \\
\hline Wet-Dry transition & 49.23 & 48.36 & 43.21 & $46.93 \mathrm{~A}$ & $0.827^{\mathrm{II}}$ & \\
\hline Mean & $43.39 \mathrm{a}$ & $44.40 \mathrm{a}$ & $40.93 a$ & 42.91 & $0.873^{\mathrm{I}}$ & \\
\hline \multicolumn{7}{|c|}{ Mean leaf length (mm) } \\
\hline Wet & 203.80 & 197.73 & 190.05 & 197.19A & $0.821^{\mathrm{III}}$ & \multirow{3}{*}{11.44} \\
\hline Wet-Dry transition & 187.34 & 182.95 & 185.36 & $185.22 \mathrm{~A}$ & $0.407^{\mathrm{II}}$ & \\
\hline Mean & $195.57 \mathrm{a}$ & $190.34 \mathrm{a}$ & $187.71 \mathrm{a}$ & 191.21 & $0.780^{\mathrm{I}}$ & \\
\hline \multicolumn{7}{|c|}{ Mean sheath length (mm) } \\
\hline Wet & 200.50 & 206.87 & 223.75 & $210.37 \mathrm{~A}$ & $0.008^{\mathrm{III}}$ & \multirow{3}{*}{15.50} \\
\hline Wet-Dry transition & 165.45 & 182.22 & 180.00 & $175.89 \mathrm{~B}$ & $0.754^{\mathrm{II}}$ & \\
\hline Mean & $182.97 \mathrm{a}$ & $194.54 \mathrm{a}$ & $201.87 \mathrm{a}$ & 193.13 & $0.358^{\mathrm{I}}$ & \\
\hline \multicolumn{7}{|c|}{ Tiller population density (tillers $\mathrm{m}^{-2}$ ) } \\
\hline Wet & 637 & 748 & 776 & $720 \mathrm{~A}$ & $0.459^{\text {III }}$ & \multirow{3}{*}{13.66} \\
\hline Wet-Dry transition & 631 & 715 & 695 & $680 \mathrm{~A}$ & $0.842^{\mathrm{II}}$ & \\
\hline Mean & $634 \mathrm{~b}$ & $731 \mathrm{a}$ & $735 \mathrm{a}$ & 700 & $0.010^{\mathrm{I}}$ & \\
\hline
\end{tabular}

Means followed by similar lowercase letters within rows and uppercase letter within columns are not significantly different at $\mathrm{P}<$ 0.05 (Tukey's test). P value: I - treatment; II - interaction; III - season. CV\% = coefficient of variation.

The lowest TPD was found at the lowest RLB length $(2 \mathrm{~cm})$, with no difference between the 4 $\mathrm{cm}$ and $6 \mathrm{~cm}$ RLBs. This reduction in TPD is not commonly observed in the literature, because the number of tillers tends to increase as canopy height decreases, stimulated by the higher quantity and quality of radiation reaching the bottom of the canopy (ALEXANDRINO et al., 2011; SANTOS et al., 2010; SBRISSIA; SILVA, 2008). The pre-grazing height is the primary regulator of the amount and quality of radiation at the bottom of the canopy and this was standardized for the different RLB lengths. However, the post-grazing height was modified by the different RLB lengths, with the highest value at the highest RLB length, although this difference was small. The highest defoliation intensity might have altered the assimilate balance of plants, thereby reducing the TPD either by decreasing the current photosynthesis during post-grazing or by the higher demand for the mobilization of organic reserves. 
Therefore, the plants might have prioritized the existing tillers to the detriment of new tillers.

Because treatments altered the RLB length, they resulted in different post-grazing LAIs and interception of PAR (Table 4).

The leaf blade is an essential component for the total dry matter production and is also responsible for most of the light interception, thereby representing a substantial constituent of the active photosynthetic tissue (ALEXANDRINO et al., 2004). Consequently, grazing management strategies that modify or alter this component directly influence LAI, PAR, and the rest period. Therefore, the lower the residual LAI, the longer the rest period that is required to reach the target pre-grazing condition (RODRIGUES et al., 2014). In the present study, the post-grazing LAI (1.78) and PAR (57.90\%) were lower at $2 \mathrm{~cm}$ than that at 6 $\mathrm{cm}$ RLB, resulting in an increase in the rest period from 30 to 37 days. This is related to the assimilate balance of plants as previously discussed and it might have contributed to the reduction of TPD at the lowest RLB length.

Table 4. Pre- and post-grazing leaf area index (LAI), interception of photosynthetically active radiation (PAR), and rest period in Piatã grass pastures.

\begin{tabular}{|c|c|c|c|c|c|c|}
\hline \multirow{2}{*}{ Season } & \multicolumn{3}{|c|}{ Treatments } & \multirow{2}{*}{ Mean } & \multirow{2}{*}{$\operatorname{Pr}>F$} & \multirow{2}{*}{$\mathrm{CV} \%$} \\
\hline & $2 \mathrm{~cm}$ & $4 \mathrm{~cm}$ & $6 \mathrm{~cm}$ & & & \\
\hline \multicolumn{6}{|c|}{ Pre-grazing LAI } & \multirow{4}{*}{16.08} \\
\hline Wet & 5.36 & 5.91 & 5.14 & $5.47 \mathrm{~B}$ & $0.004^{\mathrm{III}}$ & \\
\hline Wet-Dry transition & 6.80 & 7.40 & 5.84 & $6.68 \mathrm{~A}$ & $0.533^{\mathrm{II}}$ & \\
\hline \multirow[t]{2}{*}{ Mean } & $6.08 \mathrm{ab}$ & $6.65 \mathrm{a}$ & $5.49 \mathrm{~b}$ & 6.07 & $0.039^{I}$ & \\
\hline & & t-grazin & & & & \multirow{4}{*}{17.42} \\
\hline Wet & 1.48 & 2.14 & 2.27 & $1.96 \mathrm{~B}$ & $0.004^{\mathrm{III}}$ & \\
\hline Wet-Dry transition & 2.09 & 2.43 & 2.75 & $2.42 \mathrm{~A}$ & $0.592^{\mathrm{II}}$ & \\
\hline \multirow[t]{2}{*}{ Mean } & $1.78 \mathrm{~b}$ & $2.28 \mathrm{a}$ & $2.51 \mathrm{a}$ & 2.12 & $0.003^{\mathrm{I}}$ & \\
\hline & & -grazing & & & & \multirow{4}{*}{4.01} \\
\hline Wet & 84.11 & 87.08 & 84.10 & $85.10 \mathrm{~B}$ & $0.002^{\mathrm{III}}$ & \\
\hline Wet-Dry transition & 90.10 & 91.31 & 87.61 & $89.67 \mathrm{~A}$ & $0.623^{\mathrm{II}}$ & \\
\hline \multirow[t]{2}{*}{ Mean } & $87.10 \mathrm{a}$ & $89.20 \mathrm{a}$ & $85.86 \mathrm{a}$ & 87.39 & $0.094^{\mathrm{I}}$ & \\
\hline & & t-grazing & & & & \multirow{4}{*}{9.02} \\
\hline Wet & 52.06 & 62.38 & 63.66 & $59.37 \mathrm{~B}$ & $<0.001^{\mathrm{III}}$ & \\
\hline Wet-Dry transition & 63.74 & 68.65 & 69.94 & $67.44 \mathrm{~A}$ & $0.304^{\mathrm{II}}$ & \\
\hline \multirow[t]{2}{*}{ Mean } & $57.90 \mathrm{~b}$ & $65.51 \mathrm{a}$ & $66.80 \mathrm{a}$ & 63.40 & $0.003^{\mathrm{I}}$ & \\
\hline & & period & & & & \multirow{4}{*}{12.27} \\
\hline Wet & 39 & 35 & 30 & $35 \mathrm{~A}$ & $0.338^{\text {III }}$ & \\
\hline Wet-Dry transition & 34 & 36 & 31 & $34 \mathrm{~A}$ & $0.323^{\mathrm{II}}$ & \\
\hline Mean & $37 a$ & $35 \mathrm{ab}$ & $30 \mathrm{~b}$ & 34 & $0.032^{\mathrm{I}}$ & \\
\hline
\end{tabular}

Means followed by similar lowercase letters within rows and uppercase letter within columns are not significantly different at $\mathrm{P}<$ 0.05 (Tukey's test). P value: I - treatment; II - interaction; III - season. CV\% = coefficient of variation. 
LAI and PAR were modified by season, with higher values during the wet-dry transition in both the pre- and post-grazing conditions. This might be related to the lower MSL $(177.89 \mathrm{~mm})$ during the wet season $(210.37 \mathrm{~mm})$. Consequently, leaves became closer together, intercepting a larger amount of light, because no effect of season on number of live leaves per tiller-1 $(4.40)$, mean leaf length $(191.21 \mathrm{~mm})$, and TPD (700 tillers $\left.\mathrm{m}^{-2}\right)$ was observed. These results may be indicative of changes in canopy structure throughout the regrowth period, characterized by increases in LAI and changes in leaf inclination angle (i.e., leaves arranged more horizontally), as well as planar leaf arrangements with higher extinction coefficients making the forage canopy more efficient in light interception.

\section{Conclusion}

None of the morphogenic characteristics of Piatã grass managed under an intermittent grazing system were altered by the post-grazing RLB length applied or the season.

The MSL within season and the TDP as a function of the post-grazing RLB length were the only structural characteristics modified in Piatã grass.

The rest period of Piatã grass was inversely proportional to the post-grazing RLB length.

Both LAI and the interception of PAR in Piatã grass were decreased in the smallest RLB length.

\section{Acknowledgments}

The authors would like to thank the Coordination for the Improvement of Higher Education Personnel (Capes) for granting the scholarship.

\section{References}

AguinaGa, A. A. Q.; CARVAlHO, P. C. F.; ANGHINONI, I.; PILAU, A.; AGUINAGA, A. J. Q.;
GIANLUPPI, G. D. F. Componentes morfológicos e produção de forragem de pastagem de aveia e azevém manejada em diferentes alturas. Revista Brasileira de Zootecnia, Viçosa, MG, v. 37, n. 9, p. 1523-1530, 2008.

ALEXANDRINO, E.; CANDIDO, M. J. D.; GOMIDE, J. A. Fluxo de biomassa e taxa de acúmulo de forragem em capim Mombaça mantido sob diferentes alturas. Revista Brasileira de Saúde e Produção Animal, Salvador, v. 12, n. 1, p. 59-71, 2011.

ALEXANDRINO,E.; MOSQUIM,P.R.; NASCIMENTO JÚNIOR, D.; VAZ, R. G. M. V.; DETMANN, E. Evolução da biomassa e do perfil da reserva orgânica durante a rebrotação da Brachiaria brizantha cv. Marandu submetida a doses de nitrogênio. Revista Brasileira de Saúde e Produção Animal, Salvador, v. 9, n. 2, p. 190200, 2008.

ALEXANDRINO, E.; NASCIMENTO JÚNIOR, D.; MOSQUIM, P. R.; REGAZZI, A. J.; ROCHA, F. C. Características morfogênicas e estruturais na rebrotação da Brachiaria brizantha cv. Marandu submetida a três doses de nitrogênio. Revista Brasileira de Zootecnia, Viçosa, MG, v. 33, n. 6, p. 1372-1379, 2004.

CÂNDIDO, M. J. D.; ALEXANDRINO, E.; GOMIDE, J. A. Duração do período de descanso e crescimento do dossel de Panicum maximum cv. Mombaça sob lotação intermitente. Revista Brasileira de Zootecnia, Viçosa, MG, v. 34, n. 2, p. 398-405, 2005 b.

CÂNDIDO, M. J. D.; GOMIDE, C. A. M.; ALEXANDRINO, E.; GOMIDE, J. A.; PEREIRA, W. E. Morfofisiologia do dossel de Panicum maximum cv. Mombaça sob lotação intermitente com três períodos de descanso. Revista Brasileira de Zootecnia, Viçosa, MG, v. 34, n. 2, p. 406-415, 2005a.

CASAGRANDE， D. R.; RUGGIERI, A. C.; JANUSCKIEWICZ, E. R.; GOMIDE, J. A.; REIS, R. A.; VALENTE, A. L. S. Características morfogênicas e estruturais do capim-Marandu manejado sob pastejo intermitente com diferentes ofertas de forragem. Revista Brasileira de Zootecnia, Viçosa, MG, v. 39, n. 10, p. 2108-2115, 2010.

CUTRIM JÚNIOR, J. A. A.; CÂNDIDO, M. J. D.; VALENTE, B. S. M. Fluxo de biomassa em capimtanzânia sob três frequências de desfolhação e dois resíduos pós-pastejo. Revista Brasileira de Saúde e Produção Animal, Salvador, v. 11, n. 3, p. 618-629, 2010.

DAVIES, A. Tissue turnover in the sward. In: DAVIES, A.; BAKER, R. D.; GRANT, S. A.; LAIDLAW, A. S. (Ed.). Sward measurement handbook. 2. ed. Reading: The British Grassland Society, 1993. p. 183-216. 
DIFANTE, G. S.; NASCIMENTO JUNIOR, D.; SILVA, S. C.; EUCLIDES, V. P. B.; MONTAGNER, D. B.; SILVEIRA, M. T.; PENA, K. S. Características morfogênicas e estruturais do capim-marandu submetido a combinações de alturas e intervalos de corte. Revista Brasileira de Zootecnia, Viçosa, MG, v. 40, n. 5, p. 955963, 2011.

DIFANTE, G. S.; NASCIMENTO JÚNIOR, D.; SILVA, S. C.; EUCLIDES, V. P. B.; ZANINE, A. M.; ADESE, B. Dinâmica do perfilhamento do capim-marandu cultivado em duas alturas e três intervalos de corte. Revista Brasileira de Zootecnia, Viçosa, MG, v. 37, n. 2, p. 189196, 2008.

EMPRESA BRASILEIRA DE PESQUISA AGROPECUÁRIA - EMBRAPA. Sistema Brasileiro de Classificação de Solos. 3. ed. rev. ampl. Brasília: EMBRAPA, 2013. 353 p.

GALZERANO, L.; MALHEIROS, E. B.; RAPOSO, E.; MORGADO, E. S.; RUGGIERI, A. C. Características morfogênicas e estruturais do capim-xaraés submetido a intensidades de pastejo. Semina: Ciências Agrárias, Londrina, v. 34, n. 4, p. 1879-1890, 2013.

KÖPPEN, W. Climatologia: conunestudio de los climas de la tierra. Cidade do México: Fundo de Cultura Econômica, 1948. 479 p.

LARA, M. A. S.; PEDREIRA, C. G. S. Respostas morfogênicas e estruturais de dosséis de espécies de Braquiária à intensidade de desfolhação. Pesquisa Agropecuária Brasileira, Brasília, v. 46, n. 7, p. 760-767, 2011.

MARCELINO, K. R. A.; NASCIMENTO JÚNIOR, D.; SILVA, S. C.; EUCLIDES, V. P. B.; FONSECA, D. M. Características morfogênicas e estruturais e produção de forragem do capim-marandu submetido a intensidades e frequências de desfolhação. Revista Brasileira de Zootecnia, Viçosa, MG, v. 35, n. 6, p. 2243-2252, 2006.

MELO, J. C. Capim-Piatã (Urochloa brizantha cv. Piatã) manejado sob lotação intermitente em função da altura do pasto por bovinos na Amazônia Legal. 2014. Tese (Doutorado em Ciência Animal Tropical) - Universidade Federal do Tocantins, Araguaína.
NANTES, N. N.; EUCLIDES, V. P. B.; MONTAGNER, D. B.; LEMPP, B.; BARBOSA, R. A.; GOIS, P. O. Desempenho animal e características de pastos de capimpiatã submetidos a diferentes intensidades de pastejo. Pesquisa Agropecuária Brasileira, Brasília, v. 48, n. 1, p. 114-121, 2013.

RODRIGUES, R. C.; LANA, R. P.; CUTRIM JÚNIOR, J. A. A.; SANCHÊS, S. S. C.; GALVÃO, C. M. L.; SOUSA, T. V. R.; AMORIM, S. E. P.; JESUS, A. P. R. Acúmulo de forragem e estrutura do dossel do capimXaraés submetido a intensidades de cortes. Revista Brasileira de Saúde e Produção Animal, Salvador, v. 15, n. 4, p. 815-826, 2014.

SANTOS, M. E. R.; FONSCECA, D. M.; BRAZ, T. G. S.; SILVA, G. P.; GOMES, V. M.; SILVA, S. P. Influência da localização das fezes nas características morfogênicas e estruturais e no acúmulo de forragem em pastos de capim-braquiária. Revista Brasileira de Zootecnia, Viçosa, MG, v. 40, n. 1, p. 31-38, 2011a.

SANTOS, M. E. R.; FONSECA, D. M.; BRAZ, T. G. S.; SILVA, S. P.; GOMES, V. M.; SILVA, G. P. Características morfogênicas e estruturais de perfilhos de capim-braquiária em locais do pasto com alturas variáveis. Revista Brasileira de Zootecnia, Viçosa, MG, v. 40, n. 3, p. 535-542, 2011 b.

SANTOS, M. E. R.; FONSECA, D. M.; GOMES, V. M.; PIMENTEL, R. M.; SILVA, G. P.; SILVA, S. P. Caracterização de perfilhos de capim-braquiária em locais com três intensidades de pastejo. Revista Brasileira de Saúde e Produção Animal, Salvador, v. 11, n. 4, p. 961$975,2010$.

SBRISSIA, A. F.; SILVA, S. C. Compensação tamanho/ densidade populacional de perfilhos em pastos de capimmarandu. Revista Brasileira de Zootecnia, Viçosa, MG, v. 37, n. 1, p. 35-47, 2008.

STATISTICAL ANALYSIS SYSTEM INSTITUTE SAS Institute. SAS/STAT. User's Guide Statistics, 6.4. Cary: SAS Institute, 1996.

WOLFINGER, R. D. Covariance structure selection in general mixed models. Communications in Statistics Simulation and Computation, Philadelphia, v. 22, n. 4, p. 1079-1106, 1993. 
